This item is the archived peer-reviewed author-version of:

Time regimes in debt collection and mediation

\title{
Reference:
}

Storms Elias, Verschraegen Gert.- Time regimes in debt collection and mediation

Time and society: an international interdisciplinary journal - ISSN 0961-463X - (2018)

Full text (Publisher's DOI): https://doi.org/doi:10.1177/0961463X18767597 


\section{Time regimes in debt collection and mediation}

\section{Elias Storms and Gert Verschraegen}

Final Version published in Time and Society, 2018.

http://journals.sagepub.com/doi/pdf/10.1177/0961463X18767597

\section{Introduction}

Arriving at his first appointment for debt mediation, Quinten, a balding man in his early thirties, carries a big red binder containing paperwork. It looks more organized than it really is, he says later when having trouble fishing out some papers. Quinten used to work as an electrician at construction sites all over the country. After an illness related absence, he got into trouble with his employer and was sacked. Quinten had administrative issues when arranging his unemployment benefits and went two months without any income. He used to live problem-free, he says, but after his medical issues problems accumulated. Bills and arrears piled up. By the time he did find new employment, parts of his wages were garnished and he had little left to pay for his living expenses. This attachment "put a pistol to my head," Quinten tells the social assistant, "and then I can't do much either."

“When I don't receive anything, I can't pay my debts either," Quinten says.

His debts are varied, and include a criminal fine, unpaid income and road tax, and arrears on telephone bills. Quinten is also indebted to a friend from whom he bought a secondhand car on the promise of later payment, and to his mother who once lent him a few hun- 
dred euros when confronted with a judicial officer. According to Quinten, a total of four judicial officers have each entered his home to attach possessions.

I can try to work and earn money, but not for 4 [judicial officers] at the same time.

Quinten managed twice to prevent a public auction at the last minute by making partial payments. Just last week, he paid €200 when they threatened to take away his furniture. Quinten's attempts at negotiating with the judicial officers yielded mixed results. One receives $€ 125$ per month, another $€ 50$. Another officer didn't accept his offer of $€ 100$ per month, which to Quinten was incomprehensible.

A sudden drop in income, recurring expenses, swift collection (especially of taxes), resulting in more budgetary problems: these are continuously reappearing elements in narratives of debtors seeking help in debt mediation. Yet Quinten's account raises broader questions concerning the inherent connection between debt, collection practices, and time. How does the way in which debts are collected interfere with household budgets and personal finance? What is the role of pressure and urgency in the process of debt collection? Which temporal dimensions are at play when debtors are confronted with collection and eventual enforcement of their legal obligations?

Drawing on in-depth interviews and participant observation with multiple actors in debt collection in Belgium, this article explores how debt, collection and payment involve and enact a specific time regime, by which we mean a coercive temporal structure resulting from the coordinated practices of debt collection. With an empirical focus on both amica- 
ble and judicial collection among Belgian households and the daily work of debt mediators, we reconstruct how temporal structures, pressures and constraints are imposed on defaulting debtors. We also analyse the creative 'agency' of 'street-level' debt collectors and debt mediators who deploy timing strategies to make debtors pay their debts. Through these techniques, collection of due debts imposes certain temporal pressures and rhythms of repayment upon defaulting debtors, which are responsibilized and incited to react.

Our exploration of collection and mediation practices adds to the understanding of how time regimes regulate debt. It improves understanding of 'the everydayness' of indebtedness (cf. Deville and Seigworth, 2015) and complements the existing literature exploring how debt rearranges time for the indebted (Adkins, 2017; Guyer, 2012).

The remainder of this article is structured as follows. We start by briefly outlining the relations between debt and time, and explain how debt collection is structured by a specific time regime (section 2). After briefly situating our empirical fieldwork (section 3), we provide an overview of the main actors in the field of debt collection and mediation in Belgium (section 4). We then analyse the role of time in both amicable and judicial collection of debts, and discuss how debtors react to the pressures imposed by debt collection (section 5). The next section explores the practices of debt mediators as 'time work,' as they attempt to restructure the debtors' budgets and help with the timing of repayment (section 6). The concluding section summarises some of our main arguments, discusses what 
the article adds to the literature and highlights a few avenues for future research on time and indebtedness (section 7).

\section{Between debt and time}

The concept of debt is intricately intertwined with the notion of time. We borrow money to finance present activities \& projects and are hence obligated to repay the debt somewhere in the future. Debt can therefore be seen as a specific way of binding or producing time; it links past, present and future and creates social obligations stretching throughout time (Esposito, 2011). How debt is structuring time and is producing long lasting social obligations, has been a classic theme in sociology. When discussing money and credit in his posthumously published 'Economy \& Society' writings, Max Weber already noticed that debts are "the compensatory obligations arising out of an exchange" (Weber, 1978: 80). According to Weber, the widespread use of money makes possible the valuation of delayed obligations in monetary terms, and thus facilitates debt. Equally important for Weber was that such delayed transactions, i.e. credit, are geared to the probability that a future repayment will effectively take place. The notion of debt, then, always bridges a certain timespan, extending from a past point of origin into a future point of repayment.

Although Weber does not expand on this, it is the precise, that is quantitative, determination that distinguishes debt from other types of obligations. This numerical exactitude is crucial for one of the most famous contemporary theorists of debt, David Graeber, who writes: 
A debt is the obligation to pay a certain sum of money. As a result, a debt, unlike any other form of obligation, can be precisely quantified. This allows debts to become simple, cold and impersonal - which, in turn, allows them to be transferable. (Graeber, 2011: 13)

So far, at least two characteristics of debt stand out: precise calculability and future orientation. As a working definition, then, we suggest seeing debt as an obligation to pay a precisely quantified sum of money at a future point in time. The inevitable corollary question is when and how a free-floating promise or obligation to pay a precisely quantified sum of money at some point in the future, is transformed into a concrete obligation in the here and now when debts are due.

As pointed out by Weber, the obligation to repay debts is part and parcel of capitalist market economies. Creditors expect money lent in the past to be repaid in time and make sure that this expectation holds even when payments which ought to be made are not being made. In fact, creditors (derived from the Latin root 'credere', meaning to believe or to trust) will only keep on lending money if they can rely on the premise that debt will be repaid. "As capitalist expansion depends on credit," Jens Beckert argues, "capitalist societies must succeed in creating the expectation among capital owners that the promises at the center of credit relationships will be honoured" (Beckert, 2016: 117). This applies to debts stemming from deferred payments as well as to pecuniary loans: both are granted on the premise of future payment. Hence, capitalist societies undergird obligations of repayment by treating them as legal norms, as expectations that will continue to hold even if someone 
goes against or violates them (cf. Luhmann, 1985). To make sure that debt obligations will be honoured and not amended, creditors rely on legal procedures and intermediaries to put pressure on debtors to pay their debts.

This article will predominantly focus on intermediaries with precisely this task, such as judicial officers and professional debt collection agencies, and explore how they use timing and scheduling to collect debt. To highlight how the daily practice of debt collectors establishes specific temporal structures and imposes them on the defaulting debtor, we will use the notion 'time regime'. The concept of time regime refers to coercive temporal structures emerging from human coordination and interdependence (see Goudsblom, 2001). Social scientists have shown, for instance, how synchronization and standardization of time was an essential tool used by the state and the capitalist market to extend control over society and to regulate everyday practices such as eating, working, and consuming (Hareven, 1982; Thompson, 1967; Zerubavel, 1985). In this sense, temporality is inherently related to power, "which manifests itself in the systems of time that dictate priorities and speeds, beginning and end, content and form of the activities to be performed in time." (Nowotny, 2005: 105). With regard to debt, the notion of a time regime must therefore also refer to the sites and institutions that create binding temporal agreements, requirements and regulations, imposing a rhythm and standardized time upon debtors through the process of collection. Such debt collection occurs within a specific legal framework delineated by laws and legal principles, but equally involves deliberate action and specialised infrastructure. In our analysis, the notion of time regime directs attention towards the ar- 
ticulation and implementation of administrative and legal procedures, tables and schedules, payment plans and statutory periods.

Sociologists and anthropologists have contributed to our understanding of how such 'calendrics of repayment' (Guyer, 2012: 497; Adkins, 2017) constitute important disciplinary effects. Once a person is indebted, techniques of debt collection have the effect of focusing a debtor's attention and affectivity towards legally fixed calendrics, which prescribe how to repay his or her loan. In consonance with Foucault's conception of governmentality, we will here explore how techniques of debt collection discipline and reconfigure the debtor as an agent who should take responsibility for his or her own financial 'choices' (cf. Walker, 2012; Pathak, 2013). As the different calendrics of repayment become both more prominent and stricter in different phases of collection (as we will show in the remainder of this article), debtors are increasingly put under pressure to 'take control of their lives' by confronting different payment obligations and planning ahead for budget expenditures. To further explore this temporal dimension at the debtor's level, we will look at how debtors reconfigure the timing of their payments in line with multiple pressures imposed, but also set limits to the time regime imposed by debt collectors.

Finally, the reader should keep in mind that the time structures of debt collection are not to be considered as a monolithic whole. Although the urged priority and expected regularities of payment puts certain exigencies on the collection of mature debts, debt is regulated by multiple and different institutional and organizational time regimes. While the temporal imposition of payment priority and regularity is present in both what is called 'ami- 
cable' collection and judicial execution, the time regimes take on different forms and levels of stringency. A detailed empirical account of these two forms of collection follows in the next two sections.

\section{Data \& methods}

The analysis presented in this article is based on broader research on over-indebtedness and debt collection among households in Belgium. Due to the judicial technicalities such a topic entails, part of what is presented here is limited to this domestic legal context. It is our hope, however, that the article's general point about time regimes enacted through debt collection in its various forms is relevant to other countries and legal settings.

The material presented below is the result of fieldwork and interviews in the Flanders region, Belgium, spread over two years. ${ }^{1}$ Empirical material on debt collection in Belgium was generated through in-depth interviews and participatory observation. To become acquainted with the daily operation of amicable debt collection in Belgium, we organized five interviews with CEOs and senior debt collectors, spread over three different collection companies. Additionally, we had the opportunity to follow and interview a debt collector during his daily activities. Material on judicial collection was assembled via three interviews with judicial officers and two independent sessions of participatory observation in the collection process. Additional information on the debt collection process and legal technicalities involved was found in reference works, specialised literature, legal documents and bills. 
To gather information on the experience of the heavily indebted, two approaches were used. First, we attended 22 meetings between social workers from debt counselling services and potential clients looking for help. Three different counselling services were frequented: two which are part of governmental social services and one recent initiative launched by a judicial officer. While differences exist both between and within these organizations, they are of less significance here. During observation, field notes were kept of both the client's story and the interaction between debtor and counsellor. These notes were typed out, coded, analysed and reassembled into 'debtors' stories.' Additionally, we conducted 13 interviews with heavily indebted individuals who either formerly were or currently are in debt mediation, often in combination with other types of social assistance. For further insight into the practice of debt mediation, we held 8 interviews with experienced practicing debt mediators. All interviews were transcribed and coded, first openly and then axially, in order to fully explore the generated data.

For reasons of anonymity, all names and other identifiable attributes of respondents have been omitted or fictionalised. All interviews and field notes were originally in Dutch. Translations are our own, potential inaccuracies included.

\section{A brief introduction to debt collection and mediation in Belgium}

By focussing on debt collection we move away from approaching credit/debt as 'an indissoluble dyad' (Peebles, 2010) and instead turn our attention to the moment - or rather, series of moments - at which the everyday experience of indebtedness (cf. Deville and 
Seigworth, 2015) becomes most tangible. Before exploring the temporal intricacies of debt collection, we need to briefly introduce the different stages and actors in the world of debt collection and mediation in Belgium. Inevitably, when venturing 'out into the field,' one encounters a variety of positions, stories, and convictions. Yet, for purposes of analysis and with brevity in mind, we present the field in schematic fashion. ${ }^{2}$

\section{Collection agencies}

The website of the Belgian Collectors Association explains why debt collection is indispensable. Paying one's debts is not only a case of moral and social justice, they argue, but also of economic necessity. And this is where collection agencies contribute:

Collection agencies help businesses by collecting outstanding invoices painlessly, thus contributing to a smoothly functioning economy. ${ }^{3}$

This is illustrative of the way collection agencies present their own activities. The goal of debt collection itself is rather straightforward: getting the debtor to repay due debts. Or, as the CEO of a collection agency explained during an interview:

Small accounts or big ones, the problem is the same. You have to change the debtor's motivation to pay to green.

According to this CEO, a majority of debtors are unwilling to pay, rather than unable. He sees it as the collector's task to shift the debtor's willingness to pay from 'red' to 'green'. When convincing debtors to pay, and in contrast to judicial officers, collection agencies are restricted to what is called 'amicable collection.' The law defines amicable collection nega- 
tively by distinguishing it from judicial collection: amicable collection is "every act or practice with the goal of urging the debtor to pay an unpaid debt, excluding collection based on an enforceable title."4 In practice, this means that debt collection agencies operate 'out of court' and thus without coercive and judicial measures. ${ }^{5}$ Anyone collecting debts amicably, whether it is for themselves or for a third-party creditor, is limited to contacting the debtor with an urging message. ${ }^{6}$ The tools of amicable collection are equally basic: letter, email, telephone and home visits are used to remind debtors of their dues and to urge payment.

\section{Judicial officers}

Judicial collection, in contrast, involves a whole different set of actors and principles, and is strictly codified in the Judicial Code. A creditor in possession of an enforceable title, usually in the form of a court judgement, can call upon a judicial officer, who can then take executive measures to force the debtor to fulfil the obligation mentioned in the enforceable title. Such enforcement can take multiple forms, but judicial officers mostly work via attachment of the debtor's possessions, such as furniture and cars, or sequestration of part of his income. These resources then go (at least partially) to debt repayment. As will be discussed later, this attachment is a means to an end, rather than a goal in itself.

In the Belgian legal system, judicial officers ${ }^{7}$ are sworn public ministerial officials who have a monopoly over particular and exclusive powers assigned to them by the legislator. They serve summons to court, judgements and writs, and are responsible for the physical enforcement of court decisions and legal deeds. The nature of their employment is dual, as 
they are both self-employed and public officials. In this latter role, judicial officers are crucial for bringing court decisions 'into practice.' However, being self-employed, a judicial officer is allowed to provide services of amicable collection as well - that is, commissioned collection out-of-court and without enforceable title, similar to the collection agencies discussed above. This makes matters confusing, as in popular imagination a judicial officer is primarily associated with judges, courts and the execution of sentences. ${ }^{8}$

\section{Debt mediators}

A final actor whose involvement with time will be discussed later, is worthy of introduction here. Similar to the other actors, the role of debt mediators is peculiar to the Belgian context. Most debt mediation services are part of local social services. Depending on the size of the municipality, a number of social workers assist debtors with paying their dues. These debtors can be both regular clients of social services with a multitude of problems, as well as citizens seeking help only for their debts. Yet unlike what is often assumed, debt mediators do not take the role of personal assistant. They stand, rather, between debtor and creditor-collector in an attempt to mediate between these parties.

The aim of debt mediation ${ }^{9}$ is "to bring clarity," in the words of one debt mediator who explained that most clients have lost all overview and structure. The mediator is tasked with listing debts and creditors, mapping out a family budget, and assessing how creditors can best be repaid. What is most wanted by the debtors, the mediator continued, is peace with collectors, especially with judicial officers. A mediator from a different organisation explains that debtors usually ask for "peace and quiet." According to him, debt mediation 
is aimed at "providing space to breathe" and "taking away pressure," especially in the face of judicial collection. Moreover, by providing structure, a successful payment plan can help prevent additional steps in the process of execution and the extra costs this might involve. By assisting debtors with their financial budgets and negotiating a payment plans with the creditors, mediators provide stability to the debt relationship. In a sense, then, debt mediators too are part of the repayment process. The practice of debt mediation can further illustrate the time work involved in synchronising the temporalities of collection \& repayment with the 'lived time' of the over-indebted. But before we get to debt mediation, we must start with debt collection.

\section{Temporal pressures in debt collection}

\section{Amicable collection: regularity through reminders}

In the absence of any enforceable measures, the trade of the debt collector consists of reaching out to debtors via different means of communication, and 'amicably' impelling them to pay. Not that different from collection more than 20 years ago (see Hill, 1994), the collector spends most of his time tracking debtors and attempting to communicate with them, either via telephone, postal mail or e-mail.

Establishing a relationship with the debtor is a crucial step in inducing payment, and is part of what Joe Deville has identified as 'the capture of affect' (Deville, 2012). When exploring the role of the corporeal in the collection of unsecured consumer debt in the U.K., 
Deville highlights how collection letters themselves invite affective responses. In phone calls, too, such affect management is present. Collectors, Deville (2014: 78) writes, aim to "solidify and intensify the attachments that bind the defaulter to this particular product," and to "individualize the 'debt' in relation to the competition [of other collectors]." Similarly, the debt collectors we interviewed in Belgium mentioned the importance of establishing a bond with the debtor. That such a bond should be kind, as emphasized by one CEO, serves an instrumental purpose: it makes the collector's pleas much more difficult to ignore. Which means of communication is best suited to establish such a relationship depends on the assessed character of the debtor. As explained by a senior debt collector:

No person is the same, no [two debtors] can be approached in exactly the same manner. [...] There are cases in which I choose to never send a letter or an e-mail [...] because contact by phone yields the best results. [With others] it is not possible to have contact over the telephone, [they] are much too defensive, and then we choose to work via e-mail.

Whatever the means of communication, the collector's message provides a sense of urgency, attempting to transform the outstanding debt into something the defaulter needs to act on immediately. In writing, the urgency of the matter is underscored by capitalising certain words or printing them in bold, such as the terms within which payment is expected and possible future action when payments are not met in time. Through their communication, both by aiming to instil a sense of urgency and by imposing deadlines, collectors engage in 'time work' (Flaherty, 2011), hoping to shift the debtor's temporal experience, sense of 
priority and timing of payments. Through this time work, then, the debt collector attempts to elicit an affective response from the debtor by creating an intensified affectual relationship with time and deadlines. This time regime has to be affective for it to be effective.

Because they are limited to 'amicable' collection, these agencies cannot deploy any judicial measures which would force the debtor to pay. Collection agencies themselves emphasize on their websites and in interviews that such approach is preferential both in terms of time and cost of collection. In practice, however, judicial measures and legal means are important as means of last resort, collectors added in interviews. Although they have to be careful with direct threats of legal prosecution, they will often hint at legal action. ${ }^{10}$ Potential litigation and judicial enforcement always looms over the interaction between collector and debtor. Even in amicable collection, the judicial and legal dimensions are always present.

The collection strategy takes shape in negotiation with the commissioning creditors, explains the marketing manager of a collection company. Often, he emphasises, the creditor will simply ask to collect as much of the debt as possible, regardless of the debtors situation or customer relations, at which point it is the agency that independently maps out a policy, based on their knowledge and experience. Within this framework, however, the approach can still be tailored both to the collector's experience, but also to his assessment of the debtor and his financial capacities. This space for customization, what was called a 'made-to-measure' approach by one senior collector, is crucial. The marketing manager again: 
[The collector] has some room to manoeuvre, which allows him to play into the debtor's paying capability. It's useless to impose on someone in a really dire financial situation a payment plan he can never follow.

Earlier in the interview, the same marketing manager emphasized the importance of segmentation: distinguishing between different types of debtors and attuning the collection strategy accordingly. ${ }^{11}$

Legally-speaking, a creditor is entitled to full payment of all due debts, which implies the debtor does not have a guaranteed right to pay in instalments. When it comes to collecting debts, however, paying in parts is a pragmatic solution for households with small budgets. This is why the negotiation of payment plans is one of the collector's main tasks. The precise modalities of such plans, i.e. how much is to be paid when, are highly variable and depend on the collector's assessment of the debtor's situation and solvency. A senior debt collector explained how contact with the debtor is always a matter of "putting things into perspective," which requires filtering: "is this something I have to take into account, or is it... just some story?"

When negotiating a payment plan, the aim of the collector is double: to keep the number of payments low to receive the total sum as fast as possible, but also to quickly receive a first payment. ${ }^{12}$ In a negotiation over telephone we observed during fieldwork, the debtor promised to pay $€ 80$ monthly starting next month, while also agreeing to deposit $€ 10$ the very next day. Negotiating plans with high monthly payouts is only half of the collectors' 
task; they also need to ensure that the plans are executed. In the words of the marketing manager:

We speak of a promise to pay. Such a promise to pay is sometimes not followed through, but then it is necessary to [go after it].

Continuously reaching out to debtors who already agreed to pay, is therefore essential. Here the collection agency's specialised infrastructure plays an important role; with its detailed history and automated reminders it assists in keeping track of time and due payments. One main advantage collection agencies collection agencies emphasise when presenting their services online and in interviews relates to this supportive infrastructure, consisting of continuously refined and adapted software and hardware. This technical backbone assists with tracking different steps in the process of collection, provides a history of communication, and warns the collector when a debtor misses a deadline. Each record contains parameters such as claim reference, priority and status indicating the current state of affairs. More importantly, the system functions as an automated calendar: for every debt, a reminder is set to a specific date on which either payment is expected or action required. Take the following example observed at a collection agency. A debt of almost $€ 10,000$ is nearly paid in full: thanks to payments of $€ 150$ per month, the outstanding balance has been reduced to €290. This month, however, the debtor once again skipped payment. Adam, the collector, explains that this has happened a few times already and attempts to call the defaulter. As his calls are left unanswered, Adam decides to send a 'customized letter' in which he asks the debtor to settle the remaining balance as soon as 
possible. In another example of the need for well-timed reminders, Adam had already sent three letters to a family defaulting on school fees without any response. Finally, a home visit yielded €40 in cash and a promise to settle the remaining balance with five monthly payments of €198. The first of these instalments should have arrived 4 days ago, so Adam decides to make a telephone call. Upon recalling the agreed upon payment plan, the debtor promises to pay tonight. The collector agrees, but decides to send an additional e-mail to remind the debtor of his promise. Adam adjusts the record's status in the computer to 'promised payment' and moves on to the next debt. Similar situations often occur, Adam explains. In some cases, he has to call for each monthly payment.

Continuous reminding is the bread and butter of debt collection. Whenever the debtor is late with payments, the collector will remind the defaulter of prior agreements - be it the debt itself or a payment plan. Or, more accurately, the software system will first remind the collector of the expected payment, after which the collector decides which steps to take. The automated calendar helps collectors to closely observe payment plans and to react quickly when deviations occur. To summarise, then, the very core of amicable debt collection consists of repeated (attempts at) contact with the debtor, to establish an initial relationship or as a reminder to pay the agreed instalments. Especially when multiple reminders are sent to make sure debtors follow the payment plan, the collection agency imposes a strict regime of temporal regularity. 


\section{Judicial collection: enforced rhythm}

To explore temporal regimes at play in judicial collection, we first need to sketch the basic procedure of judicial enforcement with attachment of moveable property. This overview, however, is severely simplified and will disregard important details and exceptions. ${ }^{13}$ As explained earlier, an enforceable title is a strict prerequisite for any executive action to be undertaken on behalf of the creditor. Such a title is usually a court order, a notarial deed, or - when the government is creditor - an administrative document conferring enforceability. This legal document grants the collector, or rather the judicial officer he employs, additional power with which the debtor can be forced to pay his debts.

Before any means of enforcement can be deployed, the judicial officer is required to serve the executionary title on the debtor, after which the 'payment order' can be delivered: a writ formally ordering the debtor to pay the outstanding amount. The payment order is a final warning and last chance for the debtor to follow the verdict of his own free will. After at least one day has passed, the road to attachment is open. Attachment is a technical legal procedure through which a judicial officer can take possession of a part of the debtors income and other valuables with the goal of allocating these towards debt repayment. Various types of attachment exist, but in the case of judicial debt collection among consumers, seizing possessions or taking a part of the debtor's income are the most common.

For attachment of possessions, home visits are required. During such visit, the judicial officer can enter rooms of the dwelling where the debtor lives, taking note of moveable assets. If needed, the officer can call upon law enforcement and a locksmith to gain access to 
the home of the debtor. But even if he does not enter the dwelling, the judicial officer can write down goods he observes from the outside. ${ }^{14}$ The result is a detailed record of attachable goods found in possession of the debtor.15 Contrary to popular understanding, attachment does not yet include the removal of these assets, which is a separate fourth step: the removal and transportation of these goods can take place at the earliest one month after attachment. In the past, subsequent sale by public auction was announced and billed at the residence of the debtor. While auctions are still announced publicly, they no longer mention the debtor's identity. Finally, earnings of this sale are distributed proportionally among registered creditors.

Each of the steps outlined above implies an extra cost: compensation for litigation, serving writs \& payment orders, attachment of possessions, locksmith and police, remuneration of moving company, and finally public sale are only some of the extra costs to be reimbursed by the debtor. These costs are laid down by royal decree and cannot be written off, which means that they are payable by the debtor - or, if he is insolvent, the creditor. Any partial payment will first be allocated to these costs of execution, before any remaining sums are used to settle the original debt. In practice, this also means that 'original debts' can multiply several times in size due to the costs of these executionary steps. Cases with debts growing from an original $€ 50$ to a final bill of $€ 1000$ or more, though exceptional, are not unheard of (cf. example below).

Not all these steps are necessarily carried out. When conceived as an 'executionary pyramid' (Van Loon and Delrue, 1994), only a fraction of the cases in judicial collection 
reach the top and result in public sale of attached goods. In many cases, the debtor will pay - either partially or in full - before it comes to this final step. In other instances, the judicial officer can, for example, inform his client of the financial situation of the debtor. Based on this financial assessment, they can decide to halt execution if the costs of these steps would exceed expected returns (because of the limited worth of the debtor's assets), or when the debtor only has possessions exempted from attachment. Similarly, a payment plan may be agreed upon at any time during the execution - if the parties involved can reach agreement.

Timing and scheduling are thus of vital importance to the judicial officer's activities. Strict intervals and terms must be heeded at the risk of the process of execution being nullified. This temporal dimension is not only crucial when enforcing obligations to pay, but is important in all of the judicial officer's legal tasks. For example, serving summons, too, involves strict legal terms and deadlines. ${ }^{16}$ As one judicial officer phrased it:

Judicial officers are creatures of terms \& deadlines. [We] have to consider many terms, both towards steps in the procedure, as for the statute of limitations.

This temporal dimension with obligatory waiting periods allows the debtors subject to execution to exercise secured rights and gives them the opportunity to exhaust remedies. Additionally, as emphasized by the same judicial officer, these waiting times give debtors the space to gather required sums or propose a payment plan. Within this legally required time frame, and similarly to amicable collection, judicial officers can, according to their 
own judgement and based on experience, decide to postpone certain steps or make additional attempts to establish communication.

At each step, the communication by judicial officers to the debtor radiates a sense of urgency. Much like collection companies in the amicable process, they too emphasise the need of swift action and thus attempt to capture the affect of the debtor. This is made explicit by mentioning specific terms within which payments are expected. In contrast to amicable collection, however, the judicial officer's urging can be backed up by real threats. When collecting overdue taxes, one judicial officer writes, for example:

May I request you to deposit this amount by making use of the attached transfer form. In default of full payment or proposed arrangement within eight days, I have the formal order to serve the enforcement order and to proceed to execution, at your expense and with all means allowed by law. (emphasis in bold in original)

In another example, a judicial officer sends a reminder about impending attachment and the additional costs this involves:

Consequently, I regret to inform you that, in the absence of immediate payment or first instalment on the bank account mentioned above, we will SHORTLY proceed to ATTACHMENT of your furniture and goods.

If no one is present, I wish to inform you that a locksmith will be instructed to open doors, in presence of the police. (emphasis in bold and capitals in original) 
While collection companies, too, can emphasise urgency and even refer to possible legal action, only judicial officers can make these threats specific.

Through execution, discussed above in the form of attachment of possessions, the creditor and judicial officer force themselves directly into the lifeworld of the debtor. Yet the goal of execution is not the sale itself (which often generates few, if any, net proceeds), but rather to incite payment. As stated by one judicial officer:

Each step involves extra costs and lengthens the procedure. The goal is not taking away possessions. The goal is resolving a case.

Another judicial officer was even more direct:

Attachment is first and foremost a means of creating pressure. The goal is not to sell, but to let the debtor pay. [...] Cars are the easiest [way to achieve this], they hurt the most.

Attachment, like preceding communication with the debtor, is intended to increase pressure to pay. In the case of low-income households with multiple debts, attachment is part of a competition between collectors. In the words of a legal adviser a poverty organisation:

Judicial officers themselves say: 'Yeah, we know these household effects have very little worth [...] but we do this to stir them up,' so they know that the disposable income available at that moment will come [to them] first. It is also a struggle between collectors. [...] [The judicial officer] who exerts the most pressure receives. 
Similar to the pressurising in amicable collection discussed earlier, judicial officers attempt to instil a sense of urgency through their communication and actions. Doing so, they, too, attempt to 'capture the affect' of the debtor. Yet, in contrast to the collection agencies, the judicial officers are not limited to affective techniques, as their words are backed by the monopolistic legal powers they derive from their mandate.

One final component and parallel to the operations of collection agencies is important here: the expected and imposed regularity of payments. As with amicable collection, agreed payments are tracked with great attention. Unlike payment plans in amicable collection, however, deviation from the prescribed timing can be costly, precisely because the implied additional costs are borne by the debtor. This can be illustrated by an extreme but telling example. ${ }^{17}$ After falling into arrears, the total debt on a hospital bill soared from an original €23.63 invoice to a total of €817.58, due to costs of litigation, attachment of possessions, and other executionary steps involved. Only after the judicial officer announced the removal of attached possessions did the debtor start paying in instalments of $€ 50$, each payment adding an additional 'right of payment' charge of €4.90.18 After ten months of regular instalments, the debtor stopped paying. Within two months, the judicial officer decided to announce, again, the removal and public sale of attached possessions. This entailed extra charges for the debtor, leading to an additional cost of €182.10. This example illustrates how a rhythm of payment is imposed, i.e. by sanctioning deviation, which in turn can lead to additional debts. ${ }^{19}$ Skipping the regular payments resulted in prompt pecuniary punishment and the resumption of attachment. Through the threat of execution 
and concomitant additional costs, paying off debts in judicial collection is subject to an ineluctable calendar.

\section{Debtors' responses to the pressures imposed by debt collection}

How do debtors react to the increased pressure to pay? First and foremost, the debtor's assessment of payment priority is related to perceived urgency. This order of importance is influenced by threats of execution, a topic that emerged during interviews with debt mediators and heavily indebted heads of households alike. Debts in which judicial officers are involved are deemed more urgent and are prioritized over other due payments, even if this implies postponing other important or recurring expenses.

Debtors with limited means have severe difficulties in responding to different urges for payment priority, and continuously have to micro-manage the timing of their payments (cf. Hohnen 2007; Streinzer 2016). Shifting payments, deliberately exceeding deadlines and balancing payment priorities are all part of their budgetary strategy, as illustrated by an interview with Uma, debtor and mother of three:

So from the moment they start calling again, I make sure to always be just ahead of them [...]. Yesterday I was paying bills, and thinking should I do this [now] or... No, because then the other payment might suffer, and I still have to pay that, and I have to keep some money available for the rest of the month [...]. You have to draw a line somewhere. And taking food away from my children, that I won't do. 
In order to match the different budgetary obligations, debtors are required to shift with the timing of their payments. When deadlines conflict with one another, different payment obligations have to be carefully balanced. Additionally, the above excerpt illustrates how debtors are pressured to meet incommensurate types of obligations. Uma is not only a debtor confronted with unpaid electricity bills for which collectors will come after her, she's also a mother with moral obligations towards her children. Although she has multiple subjectivities, she only has one single budget. By setting relations they consider sacred above other considerations, debtors like Uma try to manage and balance the different obligations laying claim to their budget. They largely accept the time regime that is imposed upon them, yet also set limits to it.

In another interview, an elderly and chronically ill couple explained that their 'illnesses take precedence' over other hospital debts. Even though they claim to be very willing to pay off their outstanding debts, recurrent pharmaceutical bills take priority in their monthly budget. For them, too, timing is crucial in their budgetary management. To his frustration, 'after 45 years of paid labour', the husband receives his pension only on the 14th of each month, while his wife has to wait until the 24th. Because of this temporal cycle, they can only pay regular bills and medical expenses in the second half of each month. Both examples demonstrate how time regimes of the indebted are reconfigured in line with the pressures imposed by debt collection, but are also partly resistant to this pressure. By prioritizing urgent needs and intimate relations over other due payments, they set limits to the time regime imposed by debt collectors. 


\section{Debt mediation as time work}

Back at the debt mediation services, the caseworker wonders how Quinten manages his monthly bills and dues, given he is paid on a weekly basis. How does he decide what to pay when? Quinten explains that he agreed with his landlord to pay rent weekly. Other pecuniary obligations are met when they arrive. A list of Quinten's debts has already been made, but before any debt mediation can take place, an overview of Quinten's monthly budget is crucial. His wages are no longer attached by judicial officers, and despite weekly fluctuations in his income, it is estimated that about $€ 400$ per month will be available for settling his debts. Yet the mediator is concerned that the puzzle might be more complex. Especially potential future expenses are of concern. Quinten's second-hand vehicle, which he bought from a friend and still owes money for, is in a dilapidated state. Without his car Quinten has no income, and without budgetary surplus no mediation is possible. They talk about the state of his car, its brand and age, in an attempt to estimate potential costs in the near future. When discussing his income, Quinten mentions he will receive his holiday pay next month. Despite insistence of the mediator, Quinten cannot estimate how much he will receive. For successful mediation, an accurate and thorough budgetary plan is vital. Contingencies such as potential expenses and shifts in income add to the complex puzzle that is budgeting in debt mediation. Turning to practical arrangements, the mediator asks when Quinten will pay them, so that they can distribute his payments among creditors. ${ }^{20}$ They agree that he will make his payments weekly. Every four weeks, the mediator will pay the creditors. 
The goal of mediation is repaying debts while guaranteeing a basic living standard for the debtor and preventing additional debt-related costs. To do so, mediators must re-establish the overview lost by debtors themselves, both in terms of how much is owed to whom, and in relation to what is due when. Working towards debt relief, then, requires (re)scheduling payments and renegotiating deadlines.

When discussing the temporal pressures of judicial collection above, we showed an example where a judicial officer asked for overdue taxes to be paid "within 8 days." At the time the letter arrived, the debtor in question was enrolling in debt mediation and budgetary assistance at the social services. The debt mediator explained the situation to the judicial officer via e-mail and asked for extension of time for payment, proposing to pay the complete sum in two months at the latest. The collector agreed on the condition that payment would arrive punctually. Here, the fact that the sum was relatively small, €74.34 in total for a principal sum of €36, presumably added to the judicial officer's leniency.

Interventions like these constitute the core of the debt mediator's daily activities. The centrepiece of debt mediation is the payment plan drawn up by the mediator. To pay the different creditors, the mediator must first fit income, regular expenses and debt repayments into a single budget. Next, the mediator allocates the budget for repayment to the different creditors. The result of this puzzle is a payment plan that details both level and timing of the instalments creditors will receive. As the number of creditors increases, the timing of payments becomes more difficult. To decide which payments are best made when, the mediator considers the urgency of different debts, their respective amounts, and the esti- 
mated tenacity or flexibility of different collectors. The timing of different payments is crucial in at least two aspects. By focussing on smaller sums first, often paying these in full rather than in instalments, a larger monthly budget becomes available for the remaining debts. This is important, because the higher the debt, the bigger the instalments need to be in order to convince the creditor of the payment plan. Rather than splitting the budget amongst too many debtors at once, the mediator will ask some creditors for extension of time for payment and attempt to convince them with the prospect of higher payments once other debts have been settled. Second, the proposed payment plan always includes precise dates at which payments will be made. Regularity and punctuality of payments are emphasized in communication by both mediator and debt collector when negotiating payments. In contrast with debtors' own negotiation attempts, promises made by mediators and social services are deemed more credible, both because of their specialized knowledge and language, and because the collector can be relatively sure that payments will arrive on time thanks to the organizing efforts of the mediator.

Through the payment plan, mediators attempt to realign the financial and temporal constraints of the household budget with pressure to repay exerted by collectors. Crucially, payment plans not only bring income and expenses together in a single budget, but also provide a stabilized temporal structure by temporizing payments and indicating which debts will be repaid first, and by providing both debtor and collector with a structured timeline. 
With the stability provided by such elaborate payment plan, debtors are able to get a grip on their situation. Contingencies and uncertainties over future payments are brought down to a minimum. In this sense, debt mediators assist the over-indebted in reclaiming their future. With this added stability, many debtors repay their debts independently. If required, social services can provide additional budgetary assistance. In cases of extreme indebtedness, additional judicial protection, in the form of a collective debt settlement, can be called upon..$^{21}$

These attempts to synchronise the debtor's budget with the temporal requirements of debt collection through payment plans, show how debt mediators work with time as well as money. Debt mediation entails regular instalments and the fixed rhythm of the payment plan, and thus is part of the time regime of indebtedness. Debt mediators also, however, mitigate the harsher aspects of the time regime enacted through collection agencies and judicial officers. The time regime is no longer primarily based on pressure to pay via reminders and the threat of execution, but is now structured in a mediated payment plan. Deviation is still punished: most collectors only agree with payment plans if they are followed strictly. Any sudden breaks in payment, unless communicated, still result in reminders, charges, and the continuation of execution of the obligation to pay.

To be sure, the specifics of what we have identified as 'time work in debt mediation' might be related to the legal context and role of these services in Belgium. Yet we suspect similar forms of 'time work' to be present in the work of any type of debt mediation in other countries. Just like the management of temporal experience is central to debt collection, so is 
planning, structuring and negotiating debt essential for successful assistance of the indebted.

\section{Conclusion}

We hope to have shown not only that defaulting debtors are subject to a specific temporal regime of repayment, but also how such time regimes come about. Through debt collection, collection agencies and judicial officers structure and enact specific 'calendrics of repayment'. Both in amicable and judicial collection, a strict schedule of repayment is imposed and maintained through regular reminders, increasing pressure to pay, supportive infrastructure and legal procedures. In amicable collection, a sense of urgency is expressed via specific use of language in collection letters and other forms of communication. By urging a swift response and referring to specific deadlines and time windows, the collectors attempt to reshape the debtor's 'calculative space' (Deville, 2014: 481). Through the close tracking of the timing of promised payments and swift response to deviation of the plan, collectors attempt to extract regular payments from their debtors. In judicial collection, with its greater means of enforcement backed up with legal power, the resulting time regime is much more stringent and becomes more coercive. With an emphasis on legal execution and most notably the threat of attachment, sale, and accompanying additional charges for the defaulting debtor, judicial collection imposes a much more pressing time regime: any temporal deviation from regular payments can be heavily sanctioned, thus tightening the resulting time regime. In sum, then, collectors continuously urge, pressure 
and force the debtor to pay in time and on time: in time to prevent further action, and on time to stick to the schedule. In debt mediation, too, time plays a central role. Social workers assisting the over-indebted need to work with time as well as with budgetary constraints. By temporizing payments and negotiating payment plans with creditors and collectors, the debt mediator simultaneously restructures, alleviates and extends the time regime imposed on the debtor.

This article offers various contributions to the literature. First and foremost, it provides those who are interested in the temporal dynamics of debt with a new focus on the role of specific techniques of timing and scheduling to collect debt. While most literature has focused on how defaulting debtors balance family relations and household budgets (Streinzer, 2016; Hohnen 2007), there has been little attention for how the temporalities of debt are coproduced by the different practices and techniques involved in debt collection and debt mediation. Secondly, for scholars working in a Foucauldian framework, our analysis not only confirms the disciplinary character of debt collection techniques, but also highlights the creative agency of debt collectors and mediators, as well as the debtors themselves. Collectors and mediators skilfully use timing and scheduling to increase pressure on debtors to pay, reconfiguring the debtor's personal time and payment priorities. Simultaneously, debtors have to shift the timing of their payments in order to meet obligations related to other subjectivities and social roles. Doing so, debtors develop resistance in attempts to set limits to the time regimes imposed by collectors. Thirdly, for social policy and poverty scholars studying debt, our analysis has emphasized the importance of taking 
into account the multiple temporal requirements debtors are subjected to, both as debtors and in the form of other social obligations. Frictions between these temporal structures manifest themselves most clearly in the budgets of low-income families (cf. Hohnen, 2007). Debtors who hope to manage their finances must successfully synchronize the temporalities of debt collection to the temporal rhythms of their personal life (see also Streinzer, 2016). Failing to do so leads to more financial trouble, and potentially increases the debt. More attention to the temporal dimension of debt repayment and budgeting among low-income families, could be of benefit to research in both social work and social policy.

Finally, we note an important limitation of this study, which focussed on the interface between debtor and collector, and thus remained within the realm of microlevel interactions. Nevertheless, we expect that the temporalities of debt are equally crucial at other levels of sociological analysis. Especially when considering larger societal transformations in times of mass indebtedness, such as the rise of the 'debtfare state' and its disciplinary aspects (Soederberg, 2014), we surmise a specific debt-related time regime to be operational as well.

1 Fieldwork was completed by the first author.

2 One final preliminary consideration is in order. In the following sections, we discuss only two major forms of debt collection: out-of-court collection outsourced to specialized agencies, and collection via judicial officers. Collection exists in other formats as well: creditors collecting themselves, credit insurance companies collecting on loans extended by other creditors, and via 'debt sale' of claims to third-party collectors. Yet, during our exploration of the world of debt and collection it became clear that the two 
forms discussed here are the most prevalent. Additionally, since other forms will deploy similar collection techniques, we expect time regimes to be present there as well.

3 Online via http://www.abrbvi.be/nl/, last accessed Jun 3, 2017. Translated from Dutch.

4 Our translation of Art. 2, $\$ 1,1^{\circ}$ in Wet van 20 december 2002 betreffende de minnelijke invordering van schulden van de consument.

5 We want to stress that 'amicably' refers to 'out of court', not to any specific quality the relationship between collector and debtor might have. On the contrary, the interaction itself is often far from 'amicable'. As we will see, while the two phases are clearly distinguishable in law, amicable collection can flow seamlessly into judicial. Also note that collection is not necessarily amicable before it enters a judicial phase.

6 As of 2002, the practice of collecting consumer debts amicably and out-of-court is subject to a law which delineates what collectors can and cannot do. Interestingly, Blommaert \& Bonnaerens (2012) note that in legal doctrine multiple interpretations exist of what 'amicable collection' precisely entails - or rather, as it is defined negatively, what it does not entail. They remark that a clear understanding of what is meant in legislature is impossible without returning to the preliminary work and discussion in parliament where the Minister elucidated his legislative proposal.

7 One difficulty with presenting this specific Belgian legal context to an international audience, concerns the impossibility of accurately translating specific legal terms and roles, simply because they do not exist in all legal systems in the same manner. One of such roles is that of the 'gerechtsdeurwaarder', or 'huissier de justice' in French. Often incorrected translated as 'bailiff', their role is markedly different from that of bailiffs in Anglo Saxon legal systems.

8 The legislator recognised the possible confusion this might generate and obliges judicial officers and lawyers collecting 'amicably' to mention a specific sentence in all their writing, in a different typeface and in bold: "This letter concerns amicable collection and not judicial collection (summons to court or sequestration)." It remains highly questionable, however, whether many debtors understand this disclaimer. During interviews with over-indebted individuals, only one out of $13 \mathrm{knew}$ about the distinction between the two forms of collection (yet erroneously associated the amicable letter with sequestration).

9 In Belgium, debt mediation is only legal when offered by either lawyers \& judicial officers, or by organisations with explicit permission of the regional governments, such as local social services.

10 Judicial officers and lawyers, too, can collect amicably when they don't have an enforceable title, yet will more explicitly refer to litigation and further legal steps. See also note 7. 
11 Similar to the UK, where collection strategies are guided by econometric modelling and a calculus based on large sets of consumer data (Deville 2015: $133 \mathrm{ff}$.), segmentation is done on the basis of large amounts of debtor information. Unfortunately we had very limited opportunities to gain further insight into how these data are assembled and used.

12 Quick payment not only results in a quicker return; by making a payment the debtor also acknowledges the debt, thus interrupting the statute of limitations regardless of adherence to the promise to pay.

13 The overview is based on reference work on Judicial Law published by Laenens et al. (2016) and the website of the European Judicial Enforcement project, available at www.europe-eje.eu (last accessed on 13 March 2017).

14 During fieldwork where we joined a judicial officer attaching moveable possessions, this sometimes led to rather comical situations, with the judicial officer peering over fences, through windows and past curtains, attempting to write down any valuable possessions. We were told this was common practice.

15 Not all goods can be subject to attachment. The judicial officer cannot, for example, attach bedding needed by the debtor and his family, as listed in the Judicial Code. The same article also exempts from attachment "one cow, or twelve sheep or goats of the debtor's choice," which illustrates the law's deep historical roots.

16 In this sense, judicial officers, while establishing a specific time regime through their actions, are themselves subject to a time regime constructed through the Judicial Code and the judge of attachments.

17 The additional costs charged here are all legal. Although the multiplication of the outstanding amount is exceptional, the example is not unique.

18 When the debtor pays in instalments in judicial collection, an additional cost will be charged for each transaction. The amount of this 'right of payment' (in Dutch: kwijtingsrecht) depends on the size of each instalment. Payments of $€ 24.99$ or less accrue a charge of $€ 2.98$, while payments between $€ 25$ and $€ 124.99$ will each add $€ 4.99$ to the final account.

19 One might assume that it is in the interest of collectors to not receive full payment at once, because of charged interest and other remuneration of collectors. Brett Williams (2004: 3), for example, argues that in the United States it is in the interest of credit card agencies to receive partial rather than full payments, so that interest charges soar and more profit can be made.

In Belgium, however, the remuneration of debt collection is strictly regulated. Collection agencies work for fixed rates: they receive a sum upon collecting the debt, most often a percentage of the total debt. Most of the big collection agencies advertise their no cure, no pay approach: they charge their services only when collections are successful. Furthermore, during amicable collection among consumers, it is illegal for 
both creditor and collector to charge costs that are not mentioned in the underlying agreement (e.g., in the terms and conditions). In practice, this means that only a penalty clause and legal interest rates can be added to an overdue debt.

Judicial officers, on the other hand, do charge legal fees which can substantially increase the total debt as illustrated with the example below. These charges are strictly regulated by law and judicial officers are required to follow a deontological code that forbids them from taking unnecessary steps during the collection process.

Because of these legal limitations in Belgium, it is not automatically in the interest of collectors to prolong the total process of collection.

20 Debt mediation comes in different forms. Debtors do not always delegate monthly payments to the mediator, as in Quinten's case. On the contrary, many debtors in mediation keep control over their own finances, and will follow the proposed payment plan on their own.

21 In the late 1990s, Belgian legislators developed a legal 'collective debt settlement procedure' which, under strict conditions, grants the debtors protection from creditors and judicial officers. This procedure, while interesting from a temporal perspective, falls outside the empirical scope of this article. 


\section{References}

Adkins L (2017) Speculative futures in the time of debt. The Sociological Review 65 (3): 448-462.

Beckert J (2016) Imagined Futures. Fictional Expectations and Capitalist Dynamics. Cambridge, Massachusetts: Harvard University Press.

Blommaert D and Bonnarens F (2012) Invordering tegen particulieren en consumentenbeschermende wetgeving. In: De Grootte B, Brijs S, Volders B, et al. (eds), Invordering tegen particulieren, Herentals: Knops Publishing, pp. 121-174.

Blumer H (1954) What is Wrong with Social Theory? American Sociological Review 19(1): 3-10.

Deville J (2012) Regenerating Market Attachments. Journal of Cultural Economy 5(4): 423439.

Deville J (2014) Consumer credit default and collections: the shifting ontologies of market attachment. Consumption Markets \& Culture 17(5): 468-490.

Deville J (2015) Lived Economies of Default. Consumer Credit, Debt Collection and the Capture of Affect. London: Routledge.

Deville J and Seigworth GJ (2015) Everyday Debt and Credit. Cultural Studies 29(5-6): 615-629.

Esposito E (2011) The Future of Futures. The Time of Money in Financing and Society. Cheltenham: Edward Elgar Publishing.

Felt U (2016) Of Timescapes and Knowledgescapes. In: Scott P, Gallacher J, and Parry G (eds), New Languages and Landscapes of Higher Education, Oxford: Oxford University Press, pp. 129-148.

Flaherty MG (2011) The Textures of Time. Philadelphia: Temple University Press.

Goudsblom J (2001) The Worm and the Clock: On the Genesis of a Global Time Regime. In: van Schendel W and Schulte Nordholt H (eds), Time Matters: Global and Local Time in Asian Societies, Amsterdam: VU University Press, pp. 19-36.

Graeber D (2011) Debt. The First Five Thousand Years. Brooklyn: Melville. 
Guyer JI (2012) Obligation, binding, debt and responsibility: provocations about temporality from two new sources. Social Anthropology 20(4): 491-501.

Hareven TK (1982) Family Time \& Industrial time: The relationship between the family and work in a New England industrial community. Cambridge: Cambridge University Press.

Hill RP (1994) Bill Collectors and Consumers: A Troublesome Exchange Relationship. Journal of Public Policy \& Marketing 13(1): 20-35.

Hohnen P (2007) Having the wrong kind of money. A qualitative analysis of new forms of financial, social and moral exclusion in consumerist Scandinavia. The Sociological Review 55(4): 748-767.

Laenens J, Scheers D, Thiriar P, et al. (2016) Handboek gerechtelijk recht. 4 ed. Antwerpen \& Cambridge: Intersentia.

Luhmann N (1985) A Sociological Theory of Law. London: Routledge.

Nowotny H (2005) Time. The Modern and Postmodern Experience. Cambridge: Polity Press.

Pathak P (2014) Ethopolitics and the financial citizen. The Sociological Review, 62: 90-116.

Peebles G (2010) The Anthropology of Credit and Debt. Annual Review of Anthropology 39: 225-240.

Rinderspacher JP (1988) Wege der Verzeitlichung. In: Henckel D (ed.), Arbeitszeit, Betriebszeit, Freizeit, Stuttgart: Kohlhammer, pp. 23-66.

Soederberg S (2014) Debtfare States and the Poverty Industry. London: Routledge.

Streinzer A (2016) Stretching Money to Pay the Bills: Temporal Modalities and Relational Practices of 'Getting By' in the Greek Economic Crisis. The Cambridge Journal of Anthropology 34(1): 45-57.

Thompson EP (1967) Time, Work-Discipline, and Industrial Capitalism. Past \& Present (38): 56-97.

Van Loon F and Delrue S (1994) De onrechtstreeks gedwongen tenuitvoerlegging van vonnissen door gerechtsdeurwaarders. Rechtskundig Weekblad 58(9): 284-286.

Weber M (1978) Economy and Society. Berkeley: University of California Press.

Walker C (2012) Personal Debt, Cognitive Delinquency and Techniques of Governmentality: Neoliberal Constructions of Financial Inadequacy in the UK. Journal 
of Community \& Applied Social Psychology 22(6): 533-538.

Williams B (2004) Debt for Sale. A Social History of the Credit Trap. Philadelphia: University of Philadelphia Press.

Zerubavel E (1985) Hidden Rhythms. Schedules and Calendars in Social Life. Berkeley: University of California Press. 